\title{
THE DE-COUPLING OF NATIONAL ECONOMIC ELITES FROM POLITICAL ELITES: RUSSIA AND THE UK COMPARED
}

DAVID LANE

\begin{abstract}
The paper considers the effects of economic globalization on the relationship between national economic and political elites. It is contended that high levels of globalization lead to the de-coupling of economic elites from national political elites and that economic globalization also marginalizes the powers of dependent nation states. The thesis of this paper is that in economically globalized states there is a duality of power. A political elite is legitimated electorally to a national constituency but excluded from the nexus of power by globalized processes. The composition and balance between ruling elites diverge between nation states. A comparison is made between the British and Russian economic elites. The paper considers the composition of the boards of directors of twelve leading companies in the UK and fourteen in Russia. Attention is given to their national and educational background as well as their current or previous links with governments and economic institutions. On the basis of the biographies of directors and other company data, it is concluded that the economic elites in British companies are global in composition and decoupled from the UK's political elites. Globalization moves capitalism out of a nation state framework and neo-liberalism legitimates markets over states. Such de-coupling leads to increasing political weakness of national political elites and stimulates movements for economic nationalism. Russia is considered a hybrid system with many leading companies being closely integrated with the political elite but others are more autonomous and multinational in control and ownership. The economic structure is the basis of Russia's economic nationalism. Political leadership is considered a key variable in tipping the balance.
\end{abstract}

KEYWORDS: Globalization, Russia, UK, company boards, elites

1 David Lane is Emeritus Fellow of Emmanuel College, Cambridge University; e-mail: ds110@cam.ac.uk 
Political elites provide many necessary and useful functions: they respond to political events, they have transformative capacities through leadership and persuasion. They exercise political management, articulate and aggregate interests, and concoct legitimating ideologies. Dominant ruling elites also exclude and suppress contesting views and interests. But political elites respond to and their influence is dependent on other constituencies. Political elites are linked to structures of economic, ideological and military power. The ways such structures interact with national political elites to shape economic policy is a crucial component in promoting or undermining consensus and stability. The political dimension is dependent on social structural variables such as national and transnational corporations.

The current dominant elite paradigm may be criticised on two counts. First: it de-couples the analysis of ruling elites from social and economic structures. Ruling elites are part of, or dependent on, the support of interests which control strategic sectors and resources in society. Second: academic analysis focuses on national elites, rather than on the interaction between national and globalizing elites. This is because in the evolution of democratic control of political power, the state has been the mechanism and institution in which political power is exercised. Traditional nationally-based political elites are increasingly losing influence as the borders of nation states become porous to globalizing interests. Neo-liberal globalization has shifted political and economic power away from national to regional and global elite networks. In response to neo-liberal ideology, dominant Western national leaders have sought to connect national economic and political elites to a global type of capitalism. In doing so, national elites have been severed from their domestic constituencies.

Political power is exercised in three domains: national, regional, global. A crucial feature of electoral democracies is that they have political leaders and elites embedded in national social and economic structures. It is only in the national domain that states are the focus of electoral competition and political responsibility. The state is a crucial institution as it is the nexus through which democracy is legitimated and, if they are to be considered democratic, to which political elites are answerable. Discussion by writers working in the elite paradigm has traditionally framed elite behavior in terms of political linkages ${ }^{2}$ formed by national networks. Neo-liberal globalization has changed the configuration of ruling elite interests to the regional and global. Markets replace states as decision making bodies.

2 Higley and J. Pakulski (2007: 7) point out that in complex liberal democracies leaders are embedded in, and their effectiveness significantly depends upon, political elites: tiny groups of strategic position-holders with the organized capacity to affect political outcomes regularly and substantially'. 
The globalization of economic power is a consequence of changes in structural conditions affecting the powers of transnational corporations, national governments and international institutions. ${ }^{3}$ Such developments have weakened and marginalized national political elites. National political elites have become decoupled from national social and economic constituencies by articulating wider cosmopolitan interests. Such cosmopolitan interests exert a non-territorial form of power through policies often predicated on the ideology of neo-liberalism. This process has occurred over the history of capitalism, but reached qualitatively higher levels associated with global neo-liberalism since the fourth quarter of the $20^{\text {th }}$ century. However, globalization has unequal effects on states. The composition and power of ruling national elites have different patterns. Some elites may be more integrated into, are more dependent on, and more responsive to global than national constituencies. In these circumstances national elites become decoupled from their own constituents.

Governing political elites are in an ambiguous position. Their power is legitimated by public vote or promotion of the public good which is defined within the contours of state politics and political leadership is legitimated by a state based electoral processes. 'Democratic political elites' are responsible to the public, to the electorate. But their power and influence are dependent on linkages (for finance, sponsorship, knowledge, and endorsement) to economic, political and social constituencies which are increasingly transnational. In this context, the material or ideal interests which shape the motivations and political activities of elites and political leaders may displace the legitimate reference groups of ruling political elites. Political elites become detached from their electoral political constituencies.

The thesis of this paper is that there is a duality of power. A political elite is legitimated electorally to a national constituency but excluded from the nexus of power by globalized processes (i.e. processes which occur independently of state borders). The question that I address is how globalized capitalism impinges on different states and thus shapes the contours of political opportunity. I consider the relationship between the level of globalization and economic elite structure. It is intended to serve as an empirical example of the ways in which economic elites are fragmented by globalization and how economic nationalism may be a response. The

3 Examples are the US Organisation for International Investment, the European-American Business Council, the Global Association of Financial Institutes, the Institute of International Bankers, Transatlantic Business Dialogue, International Business Investment Network, The International Chamber of Commerce, the Trilateral Commission, the Bilderberg Conferences, The World Economic Forum, the International Chamber of Commerce and The World Business Council for Sustainable Development. These act in addition to well know organisations such as the World Bank, International Monetary Fund and the World Trade Organisation. 
extent and type of incorporation of countries into the world order of interdependent states varies greatly. In this paper, I consider only the economic aspects and restrict discussion mainly to two polar examples: the UK and the Russian Federation.

\section{VARIATIONS IN THE LEVEL OF GLOBALIZATION}

Developments since the last quarter of the $20^{\text {th }}$ century have involved a significant de-territorialisation of national capitalisms. But the significance of such changes is open to question. Kenichi Ohmae, Colin Crouch and Leslie Sklair, on the one side, consider the state to be compromised in the face of the power of international and global companies (Ohmae: 1995, Crouch:2010, Sklair 2002). Under such conditions, political elites based on the nation state are severely constrained as political power becomes internationalised in scope. The global economic market undermines not only political democracy which operates at a state level, but also gives rise to national political elites who are dependent on international interests (institutions like the IMF and global corporations). Other commentators, like Peter Dicken (2003) and Michael Mann (2013), contend that the state retains significant powers.

Much of the confusion is derived from considering global capitalism as a unitary world-system, rather than as a collection of states and regions having different economic structures and historical trajectories. The world system is made up of many states and regions and not all are equally subject to global corporations and to neo-liberalism. The vehicle of globalized capitalism is the transnational corporation ${ }^{4}$.

Economic globalization has two dimensions. First, parent companies 'colonize' domestic companies through take-overs then create wealth in the form of investment and employment in the host countries while returning home profits. This is the basis of dependency for host countries - they have no jurisdiction over foreign parent companies. The significance here is that such asset transfers to host countries

4 Transnational corporations (TNCs) are constituted of parent enterprises and foreign affiliates. A formal definition of a transnational corporation (TNC) is that it is 'an incorporated or unincorporated enterprise comprising parent enterprises and their foreign affiliates. A parent enterprise is defined as an enterprise that controls assets of other entities in countries other than its home country, usually by owning a certain equity capital stake'. A foreign affiliate is an incorporated or unincorporated enterprise in which an investor, who is a resident in another economy, owns a stake that permits a lasting interest in the management of that enterprise (an equity stake of 10 per cent for an incorporated enterprise, or its equivalent for an unincorporated enterprise). In World Investment Report (WIR), subsidiary enterprises, associate enterprises and branches are all referred to as foreign affiliates or affiliates. (WIR 2005: 297). 
'involve a shift in production control and management from domestic to foreign firms. . . (WIR 2009: 9) It also affects the ways in which national governments are able to manage their economies. Secondly, new parent companies in the host country develop their own regional and global pretensions which give rise to neoliberal globalizing interests. The problem which arises for governments in both parent and host countries is how to exercise their control. This applies to their own globalizing companies when their global interest (for profit, for expansion) does not coincide with the home government's policies (say for employment and social development). Political elites become 'cut off' from those with economic power. This disjunction is one of the reasons for the rise of populist parties.

Foreign direct investment (FDI) is the crucial link giving the transnational corporation a multinational character. FDI grew exponentially between 1982 and 2006. Figure 1 shows the growth of FDI outflows, cross-border mergers and acquisitions and the consequent rise in assets of foreign affiliates of transnational companies. The growth of foreign affiliates and their contribution to company sales were also of great significance.

Figure 1. Indicators FDI outflows, cross-border acquisitions an total assets of foreign affiliates: 1982-2006

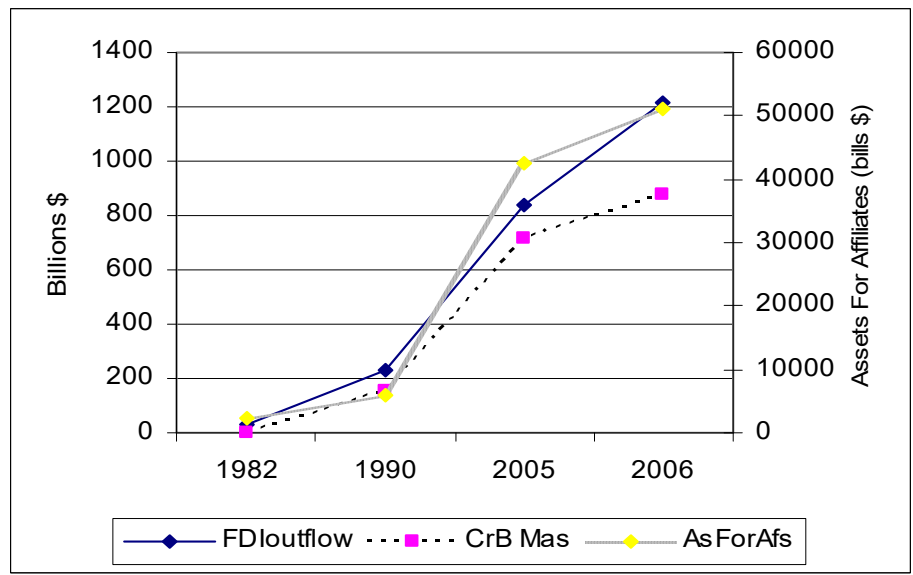

Key

CrB Mas Cross-border Mergers and acquisitions 
The results of this economic colonization is shown in Table 1 which shows the number of parent corporations as well as the foreign affiliates in different states and groups of states. It brings out the disparities between the numbers of parent companies and affiliates in different countries. The European countries, Japan and China house transnational parent companies. The USA and the UK have large numbers of parent companies and both host foreign affiliates - though the USA (with a far larger economy) has far less affiliates on its shores than the UK. Japan hosts fewer affiliates than its parent companies. China and the New Member States of the European Union host literally thousands of foreign companies. The New Member States of the EU, with a much lower population, have ten times more TNC affiliates than the CIS 5 . These differences have significant implications for the class and elite structure.

Table 1: Parent Corporations and Foreign Affiliates of Transnational Companies:

South America, CIS and New Member States, East Asia, China, USA and UK (2010)

\begin{tabular}{|c|c|c|}
\hline & Parent & Foreign \\
\hline & Corporations & Affiliates \\
\hline NMS & 3063 & 130430 \\
\hline CIS & 176 & 3487 \\
\hline USA & 9692 & 27251 \\
\hline UK & 7398 & 45466 \\
\hline Japan & 4543 & 2948 \\
\hline \multicolumn{3}{|l|}{ South } \\
\hline America & 807 & 10349 \\
\hline $\begin{array}{l}\text { East Asia } \\
\text { Of which }\end{array}$ & 20955 & 450589 \\
\hline China & 12000 & 434248 \\
\hline
\end{tabular}

Since the beginning of the industrial revolution, the UK has had significant international trade and British companies and British share holders had vast investments abroad, particularly in the colonies. From the late twentieth century, however, the pattern of ownership began to change. British companies were purchased by foreigners and cross border mergers and acquisitions strengthened transnational corporations. As shown in Fig 2, the UK, while retaining a large number of parent companies, also hosts an even larger number of affiliates.

5 In these tables 'CIS' refers to Armenia, Azerbaijan, Belarus, Georgia, Kazakhstan, Kyrgyzstan, Moldova, Russian Federation, Tajikistan, Turkmenistan, Ukraine and Uzbekistan. MNS are Bulgaria, Czech Republic, Estonia, Hungary, Latvia, Lithuania, Poland, Slovakia. Slovenia, Romania 
The low penetration of Russia and other CIS states by multinational corporations measures their lack of exposure to economic globalization. By 2010, only 116 parent corporations and 2139 affiliates were based in the Russian economy. Russia was (and is) one of the least economically globalized industrialised countries. As we see from the comparisons shown in Figure 2, Hungary, typically of the New Member States of the EU was heavily penetrated by transnational companies.

Figure 2. Number of parent corporations and foreign affiliates in USA, UK, Hungary, Brazil, Poland, Russia, Ukraine, Kazakhstan and Belarus (2010)

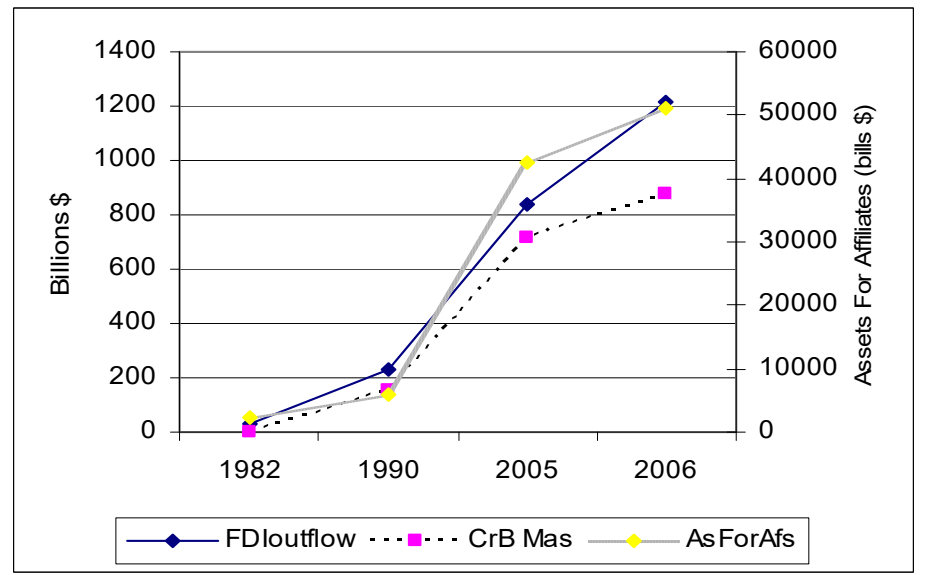

Number of parent companies in the economy shown. Right hand axis.

Number of foreign affiliates in the economy shown. Left hand axis.

Source: For 2010, WTO UNCTAD, Webtable 34. unctad.org.wir. (Annex tables). Accessed 18 May 2017. Some entries refer to earlier years. For earlier data see: World Investment Report 2007. UNCTAD, United Nations, New York, Geneva 2007. pp. 217-218.

These developments have significantly impacted on national politics. The structure and composition of economic and political elites vary between countries - depending on the extent to which their companies and industries have become de-territorialized. A major contention of writers following Crouch and Sklair is that in globalizing societies, national political elites become detached from their domestic constituencies and consequently lack effectiveness. This reasoning would apply to the post-socialist New Member States which have been fully incorporated into the world order. Their political power no longer resides in the nation state: their political elites have little power over the allocation of economic resources, they have none over tariffs. 
However, the countries of the former USSR have remained more peripheral or in contention with the hegemonic economic states. The Russian Federation moved into a globalizing mode in the early years following the breakup of the USSR and foundations were laid for a number of Russian based international energy companies. Inward FDI facilitated the entry of foreign based global firms. However exposure of Russia to the world market led to internal decay and international weakness which, to some extent, have been halted under President Putin. An implication here is that the Russian national political elite structure is far less de-coupled from the Russian economy than in other more globalized states. My hypotheses is that ruling elites in Russia have to be more responsive to domestic constituencies and less to globalizing ones. They are less constrained by external interests. Economic nationalism is built into Russian politics. Study of the composition of company boards will explore these linkages.

\section{THE COMPOSITION OF THE BOARDS OF MULTINATIONAL CORPORATIONS}

The rise and geographical distribution of transnational corporations have been outlined above. What then is the significance of the economic globalization process for the structure and legitimacy of the political elites? How do they relate to the interests of global companies? Many academics and political pundits have complained about 'stateless elites whose allegiance is to global economic success and their own prosperity rather than the interests of the nation state where they are headquartered' (Summers 2008). The literature provides little empirical backing for such generalizations to show the de-coupling of national economic elites from the political elite structure.

The growing presence of foreign interests may be evaluated by a study of the composition of boards of directors of major companies. The assumption underlying this study is not that eponymous directors are by definition more altruistic than foreigners - some are capable of plundering their companies like anyone else. Rather the significance is that when deterritorialization occurs, the socialization process breaks national links between the economic elite and the country in which the parent company is embedded. Companies have responsibilities to other stake holders and to the community, but 'the community' for transnational companies is not defined. It might be hypothesized that a multinational board is more conducive to a neo-liberal global policy than a national one, as its responsibility would be clearly to satisfy the interests of shareholders. Decisions about the location and amount of investment (and reinvestment), outsourcing, levels of employment, staff pensions and training can 
be influenced by the social and national composition of boards. Family owned firms have been shown to have a stronger inclination to maintain production in the home country and to enhance levels of domestic productivity rather than moving to cheap labor sites. For multinationals with no domestic community commitments, neo-liberal objectives of efficiency and profitability overcome any wider national, political or social aspects of company policy. A multinational board is likely to regard the shareholders as the major reference group and the scope of decision making is the wider global economy. Domestically recruited boards are more likely to pursue a policy of economic nationalism.

Study of the composition of company boards will show whether there remains any significant overlap between board members and the political elites of the parent (or any other) country. The objective is to record the source of recruitment, the social composition and national identity of the corporate elite, noting any overlap between political and economic elites. Such details also indicate the type of socialization the members have experienced. Board members with economic and political overlap are able to maintain a two-way exchange. National governments can have direct influence on the boards and vice versa.

The boards of 42 important TNCs were surveyed by UNCTAD in 2004. It was found that the percentage of non-home national directors was 33 per cent for EU companies and 18 per cent for US based corporations. Germany retained a significant national composition, with only 8 per cent of board members being non-nationals, whereas for UK based multinationals, out of a total of 102 directors 53 of the boards were foreign born with some 20 per cent coming from the EU and the same proportion from the USA. Total USA participation in EU companies was only 11 per cent (including those in UK companies). For Japan, as one might expect, out of a total of 123 directors, only 3 were foreign. The UK had the highest saturation of non-UK directors ${ }^{6}$.

The data cited by UNCTAD refer to the early twenty-first century and also ignore rising states with newly constituted companies such as Russia and China. To detail more precisely elite personal linkages between companies and government, I consider the composition of transnational company boards in two countries: the UK and the Russian Federation. These are examples of highly and less globalized economies with companies selected from the Top 2000 Transnational Companies as constituted in the Forbes List. The members of the boards are then described from the biographies of directors as published in the company annual reports.

6 Annex Table A.I.28. UNCTAD 2004. p.38. 


\section{The Boards of British Companies}

The Forbes list of 2000 global companies ranks companies by an average of their profits, assets and market value 7 . I have selected from this list twelve companies from different economic sectors. Shell (rank 11), BP (rank 17), Vodafone Group Plc (38), Rio Tinto (109), GlaxoSmithKline (116) National Grid (168), AstraZeneca (183), HSBC Holdings (14), Barclays (161), Aviva (143), Royal Bank of Scotland (425) and Lloyds Bank (391). Comprehensive details (market value, sales, profits, assets) on these companies for 2014 or later are given in Appendix 1.

Shell plc is an icon of the multinational corporation. Until 2005 it was a dual UK/Dutch company, since then it is a single company with its headquarters in Holland but registered in London. In 2015 it was ranked in the World Investment Report as the top world company by its ownership of foreign assets. It operates in 70 countries and in 2016 had revenue of 236.6 billion dollars ${ }^{8}$. It has a single-tier Board of Directors with 12 members 9 . The Board has five American nationals, four Dutchmen, two British and one Asian member. Study of their work backgrounds shows that most had work experience in the USA (seven members) followed by Europe (five, including only one in the UK), three had worked in Asia. Four had participated in government (two in Holland) in some capacity and three had been on advisory boards or acted in an advisory capacity; one had been a British ambassador in the USA. Only four had or have directorships in other companies. The directors had experience of government, in both Holland and the USA. Apart from the British former ambassador only one other member of the board was British. American work background appears to dominate the Board.

The detailed biographies of three Board members are cited here to give the reader an account of the linkages between different companies and politics. Charles O. Holliday, a US national was appointed Chairman in May 2015, having been a non-executive director since 2010 . He previously worked in the USA from 1970 when he joined DuPont after graduating in engineering from the University of Tennessee. He has worked in Tokyo as President of DuPont Asia/Pacific. His previous jobs include Chairman of the Bank of America, he have served on the Business Council, Catalyst, the National Academy of

7 Forbes Top 2000 global companies available at: http://www.forbes.com/global2000. (Various dates). The Rankings here are taken from the 2014 list.

8 Shell plc Financial Statement 2016.

9 Data on directors taken from Shell website available at http://www.shell.com/about-us/leadership/ board-of-directors.html accessed 21 April 2017. 
Engineering, the Society of Chemical Industry, the World Business Council for Sustainable Development and Director of Deere International. He is a director of HCA Holdings.

Hans Wijers is deputy Chairman, and a Dutch national educated in economics at Erasmus University Rotterdam. He has been a non-executive directory of Shell from 2009. He has been CEO and Chairman of the Board of Management of AkzoNobel N.V. from 2003 to 2012. Other posts include: Senior Partner at The Boston Consulting Group. He was Minister of Economic Affairs of the Netherlands from 1994 to 1998. He has been Chairman of the Supervisory Board of AFC Ajax N.V. and 2013 to 2016 he was a Non-executive Director of GlaxoSmithKline plc. He also Chairman of the Supervisory Board of Heineken N.V., a member of the Supervisory Board of HAL Holding N.V. and a trustee of various charities.

Sir Nigel Sheinwald GCMG is a British national, having been appointed a Nonexecutive Director of Shell in July 2012. He is a former British diplomat having joined the Diplomatic Service in 1976 and served in Brussels, Washington, Moscow and in a wide range of policy roles in London. He was British Ambassador to the USA from 2007 to 2012. Prior to this, he served as Foreign Policy and Defence Adviser to the Prime Minister and Head of the Cabinet Office Defence and Overseas Secretariat. He served as British Ambassador and Permanent Representative to the European Union in Brussels from 2000 to 2003. He is a Non-executive Director of Invesco Limited and Raytheon UK, a Senior Adviser to the Universal Music Group and a Visiting Professor and Council Member of King's College, London.

GlaxoSmithKline in 2016 had a market value of 104.2 billion dollars, sales of 36.6 billion, profits of 12.9 billion and assets worth 78.8 billion. The company operates in over 115 countries - its largest market is the USA. and has a very large research and development operation. The Board of Directors has 11 members, composed mainly of British people (probably 7) with an Indian and a Swiss member. Only 23 joint Board memberships are listed. A distinguishing factor is the large number of members who have had an academic career or a research background. (Detail of the biographies on the company web site is very brief). The Chairman, Sir Philip Hampton is a business administrator. $\mathrm{He}$ is described on the company web site as: having "chaired major FTSE 100 companies, including The Royal Bank of Scotland Group plc and J Sainsbury plc. He has also served as Group Finance Director at Lloyds TSB Group, BT Group plc, BG Group plc, British Gas plc and British Steel plc. [He] was previously appointed an Executive Director of Lazards and a Non-Executive Director at RMC Group Plc and Belgacom SA. Until 2009, he was Chairman of UK Financial Investments Limited, which manages the UK Government's 
shareholdings in banks'. One of its directors, Vivien Cox is said on the Glaxo website to have 'a deep understanding of regulatory and government relations'. Not one director is credited with any current or previous government post.

National Grid in 2016 had revenues of 24.2 billion dollars. National grid delivers energy to consumers in the UK and in parts of the USA. ${ }^{10}$ The Annual Report divulges very little information about the background of board members. There are 6 British members, 5 Americans and a Canadian. Nearly all have or had experience on the boards of other companies. Nicola Shaw 'has a broad range of experience and strong track-record working with the UK Government, the European Commission and Parliament, with Regulators and in leading important infrastructure businesses.' Quite exceptional is the presence of a former Members of Parliament, Ruth Kelly, who served in the Labor government under Tony Blair. She held positions of Minister for the Cabinet Office and also Minister of State for Education and Skills.

AstraZeneca in 2016 made sales of \$24.2 billion. (Annual Report 2016) It is a British-Swedish multinational pharmaceutical company. It has grown by buying and amalgamating companies and retains research sites and offices in many countries including the United States, China, Brazil and Japan ${ }^{11}$. China is the company's second largest market. The Company gives very little information on the background of its board. Of the board members only one (possibly two) is British. There are two with Swedish and two with French nationality, one Dutchman and one Chinese; three are likely to be Americans. There are no recoded links with government. The non-executive chairman is a member of the European Round Table of Industrialists.

BP Global in 2016 operated in 74 countries and had an operating cash flow of $\$ 17.6$ million $^{12}$. It is a conglomerate which has amalgamated British and American firms. It includes the original British Petroleum, Standard Oil (USA), Amoco, ARCO, Burmah Castrol; it also has a 20 pr cent stake in Russia's Rosneft which displaced its earlier partnership with TNK (which lasted until 2013). The USA is its largest division.

In 2016, it had a Board of Directors with 12 members, its Chairman, Carl-Henric Svanberg, is Swedish. The chief executive, Bob Dudley, has dual citizenship with UK and USA. Its Board of Directors includes 6 Americans and 8 English

10 For details see its website: http://www2.nationalgrid.com/about-us/our-history. Accessed 23 April 2017.

11 For details of Board see: https://www.astrazeneca.com/our-company/leadership.html. Accessed 24 April 2017

12 See Annual report available at: http://www.bp.com/content/dam/bp/en/corporate/pdf/investors/ bp-annual-report-and-form-20f-2016.pdf. Viewed 21 April 2017. 
citizens (though the latter include two with joint citizenship). Study of work histories in their autobiographies reveals that there were 22 work placements (outside BP) in foreign countries compared to 7 in UK. Board members reach out to other firms and 30 directorships were reported. Five board members had direct links with politics. These however were in an administrative or advisory capacity. None had been elected. Work experience was in the USA though importantly some of the Board had experience in areas of BP production, notably Russia. Unlike Shell which has on its Board people who have held government executive positions. BP recruits people from previous elite positions: a US navy admiral and an ex chief of the British secret services among others.

Vodafone Group Plc has branches in 26 countries and has partner networks in over 50 additional countries. In 2016 it had revenue of $£ 40.973$ billion. It has absorbed many other smaller companies but in 2013 it divested for $\$ 130$ billion its share in the ownership of Verizon which has led to its current absence in the US market.

There were 14 directors on the Board in $2014^{13}$. The majority were British just half- in addition there were 2 Americans and 4 Europeans (Dutch, Italian, French and Belgian) and 1 Ghanaian. In all they held a total of 51 directorships in other companies. The most notable characteristic of the board was the hiring of people with experience from other companies. The chairman, Gerard Kleisterlee President/chief executive of Philips where he had worked for 30 years. Stephen Pusey had worked for Nortel Networks for 23 years and had been its Executive Vice-President and President. Nick Land had worked for Ernst and Young for 36 years and had been its chairman for 11 years. Luc Vandevelde had been CEO and chairman of Carrefour as well as Chairman of Marks and Spencer.

The directors had relatively little involvement in politics and none in UK politics. Vittorio Cotao, had been on the steering committee of the European Round Table of Industrialists. Valerie Gooding had been a board member of Confederation of British Industry. Of particular note is that Samuel Jonah had been an advisor to the President of Ghana and South Africa, on the advisory council and a member of the President of the African Development Bank. He has also been an advisor to the Presidents of Togo and Nigeria. Anne Lauvergeon had served as deputy chief of staff to the French Presidency and had been an advisor for Economic international affairs. None had any recorded position in British politics.

13 Vodafone Group, Annual Report 2014. Available at: https://www.vodafone.com/content/ annualreport/annual_report14/downloads/our_board_and_group_management. Accessed 22 May 2017 
The directors' profile is one of technical executives working in engineering extraction companies in many parts of the world (including Canada, the USA, Chile, Argentina, Netherlands, China, South East Asia. India and South Africa). Four have had some participation in politics. Sam Laidlaw from the UK had been a member of the UK Prime Minister's Business Advisory Group and had been a senior director at the UK Department of Transport. Anne Lauvergeon had been adviser for economic international affairs under the French President (as noted earlier). Michael L'Etrange, an Australian had been an adviser to the Australian Prime Minister and Cabinet and had served as Australia's High Commissioner to the UK before being appointed as secretary of the Department of Foreign Affairs and Trade. Paul Tellier had been a clerk of the Privy Council Office and secretary to the Cabinet of the government of Canada; he had also chaired a Prime Minister's Advisory committee. None had held an elected political role.

\section{Boards in the British Financial Sector}

The financial sector is a major player in the UK economy. In 2010, it accounted for 10 per cent of UK GDP and 11 per cent of tax receipts, it made a trade surplus of $£ 35.1$ billion, greater than all other exporting industries (pharmaceuticals made $£ 7$ billion). But British 'home' banks are not major players in the international economy ${ }^{14}$.

In 2012, the UK financial sector was dominated by five banks plus Lloyds and Santander (registered in Spain). The five top banks had between them 1479 affiliates located in from 19 to 65 countries. (See Table 2). Below I outline the background of the boards of directors of HSBC, Aviva, Barclays, the Royal Bank of Scotland and Lloyds Bank.

14 Most of the major investment banks are American, the top banks are: Bank of America, Barclays Capital, BNP Paribas, Citigroup, Credit Suisse, Deutsche Bank (with considerable presence in UK), Goldman Sachs, JPMorgan Chase, Morgan Stanley, Nomura Securities, UBS, Wells Fargo Securities. 
Table 2. British Financial Companies in Top 50 by Geographical Spread 2012 (Millions of dollars and number of employees) ${ }^{15}$

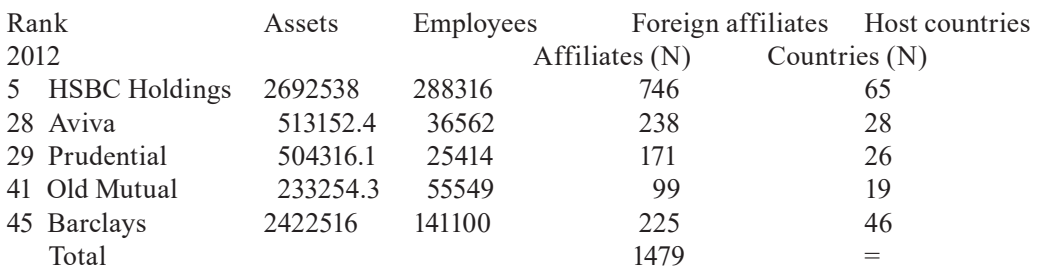

Source: data for 2012, UNCTAD.wir.Webtable 30. Accessed 26 Apr. 2017

HSBC Holdings plc, founded and registered in London in 1991, is a Chinese bank (The Hongkong and Shanghai Banking Corporation) which acquired the indigenous UK Midland Bank. It is the largest bank in Hong Kong, and the largest international bank in the Chinese People's Republic.

Study of the UK Board's membership for $2016^{16}$, confirms its international composition. Of its twenty members 7 are American, 8 British as well as nationals of Germany, Holland, Australia, and France, there is one Asian (country of origin not recorded). Of the incomplete educational records, 8 have been educated in the USA, 6 in the UK, 1 in Holland, 2 in France and 1 in Germany.

Barclays plc is a long standing British bank with a foundation in London going back to the $17^{\text {th }}$ century. The Bank bought up many other financial interests including Wells Fargo (USA), banks in South Africa, Woolwich Building society (UK), Juniper Bank (USA), Absa (S. Africa), and Expobank (Russia), Goldfish credit cards (USA) and parts of Lehman Bros. Its board as constituted in 2016 had 14 members: 7 British, 5 American one French (or Swiss) and one Zambian. The chairman in 2016 was John McFarlane who has spent over 40 years in the financial services sector. He is a Scot, educated at the University of Edinburgh. He has been chairman of Aviva, FirstGroup, and the Australian Bankers Association. He was CEO of Australia and New Zealand Banking Group and also has been an executive director of Standard Chartered, and head of Citibank in the UK.

Royal Bank of Scotland Group (RBS Group) originated in the $18^{\text {th }}$ century. It is an amalgamation of many banks - The Royal Bank of Scotland, National Westminster Bank; Williams \& Glyn's Bank, Ulster Bank; Drummonds; and

15 World Investment Report 2016. Annex Table 24, World's Top 100 Non-Financial Companies. www.unctad.org.wir. Accessed March 2017.

16 Data based on HSBC website: http://www.hsbc.com/about-hsbc/leadership. Accessed 25 April 2017 
Coutts \& Co. Direct Line and Churchill Insurance. In the USA, it owns Citizens Financial Group, it is a major shareholder in the Bank of China. Following the financial crisis it was partly nationalised by the UK government which in 2012 owns 84\% of its shares. It made a loss of 13.4 billion dollars in 2014 (see Appendix I). There are fourteen people on its board in 2016 ${ }^{17}$ : ten are British, one is French, one Canadian, one Australian and one New Zealander (nationality based on career path and education as not specifically defined in biographies). Its Chairman is Howard Davies who has been a Deputy Governor of the Bank of England and Chairman of the UK Financial Services Authority. He was Director of the London School of Economics and Political Science from 2003 until May 2011.

\section{The British Economic Elite: Some Conclusions}

Study of the direct political links of the members of the Boards of the major UK financial companies finds very little direct overlap with the political elites. Very few have had experience as executives in state governments and even fewer as elected legislators. Some when in office have been appointed to government committees and working groups. Most members of the boards of financial companies are recruited from within the industry and a small number of board members have had administrative and executive positions in other businesses. The overwhelming picture is one of a relatively autonomous elite, of executives who have worked their way to the top in the banking and financial services' sector. They appear to have had little time to devote to party politics.

In UK based companies, the boards of the transnational companies are international in composition. In most cases the majority of members are British, though all boards are multinational. Many reflect the process of mergers with foreign companies. Direct ties to their 'home' governments are weak. A very small number have had executive positions or acted on advisory bodies for short periods. In the financial sector, directors, shareholders and clients are global in character.

The company boards of UKs major companies operate with little, if any, participation by the parliamentary political elite. The executive arm of government (the Prime Minister, the Chancellor and other Ministers) deals directly with global financial interests. Many board members with previous membership of governmental bodies are useful to the company and bring

17 For details see: http://www.rbs.com/about/board-and-governance/board-and-committees

CORVINUS JOURNAL OF SOCIOLOGY AND SOCIAL POLICY VOL. 8 (2017)3S 
insider knowledge and network links to their jobs. Elite interaction is part of an international rather than a national network.

The move to multinational or transnational capitalism involves a shift away from national solidarity and a national political focus. As Jerry Harris (2006:93) puts it: globalization 'eliminates economic nationalism as the basis for social inclusion'. Global elites have no single nation. They operate in the most profitable market. Their major objectives are to secure economic rents. Class interests shape the motivations and political activities of elites and political leaders. These linkages are often under-theorised by writers on elites (see discussion in Pakulski and Körösényi: 2011).

Bottomore suggests three different types of linkage between class and elite. They are: 'complimentary concepts which refer to different types of political system or different aspects of the same political system. We can attempt to distinguish [firstly] between societies in which there is a ruling class, and at the same time elites which represent particular aspects of its interests; [secondly], societies in which there is no ruling class, but a political elite which founds its power upon the control of the administration, or upon military force, rather than upon property ownership and inheritance; and [thirdly], societies in which there exists a multiplicity of elites among which no cohesion and enduring group of powerful individuals or families seem to be discoverable' (Bottomore, 1964 (1982)).

British economic elites do not fit easily into this categorization. The companies though registered in the UK have elites which are international in character. Ownership and inheritance do not appear as important social characteristics, though responsibility to shareholders is no doubt of importance. Judging by their biographies, they have a weak or non-existent national loyalty. They appear to be relatively autonomous in operation. They have only tenuous or indirect linkages to ruling political elites. I suggest a fourth category to add to Bottomore's list which is nearest to his third category. A global economic elite, which is largely detached from national ruling elites, which operates in global space and is motivated to enlarge or make profits for economic corporations.

\section{COUPLING OF ECONOMIC ELITES TO THE POLITICAL IN RUSSIA}

Following the de-statization and privatization achieved by the Yeltsin regime, a private property owning class, headed by oligarchs - strongly backed by Western international interests - became a major factor in the social structure. However, the propertied classes lacked legitimacy and were challenged by a renewal of an administrative elite under Putin. It seeks to contain both the national and 
globalized bourgeoisie and it does this through economic nationalism. Trends towards globalization, favored by the West have been halted.

\section{Russian Transnational Companies}

In 2013, Russia had 30 companies in Forbes list of 2000 global companies ${ }^{18}$. Seven of these are in oil and gas, ten are other primary sector producers, four are energy/electricity, three are retail (including Aeroflot), two are media and one (Sistema) is a conglomerate. The top company was Gazprom (ranked 17th in Forbes) followed by Rosneft (59), Sberbank (61) and Lukoil (64). Here we consider the composition of the boards of fourteen of the Russian companies in the Forbes' lis $\mathrm{t}^{19}$. (Rankings and financial data for 2014 (with slight variations from the 2013 list) are collected in Appendix II). Study of the composition of the boards of these companies gives significant insights into their divergence from Western ones. Unlike Western based transnationals, Russian companies provide a basis for a national capitalism. One may distinguish two trends: the major one being of home-based transnationals and the minor one, cosmopolitan based transnationals. The former have considerable state ownership and control.

\section{Home-based Transnationals}

Despite the attempts by Dmitry Medvedev in 2011 to reduce the representation of chinovniki on the boards of Russian companies, many Russian transnationals are heavily penetrated by directors who have (or had) significant positions in public administration. Russian transnationals are strongly linked to domestic politics.

LUKOIL is the fourth largest Russian global company, in 2014 ranked $83^{\text {rd }}$ by Forbes. It is a vertically integrated company ranging from oil production and refining to petrochemicals and electricity generation. The company retails many of its products. Unlike Gazprom, LUKOIL has significant private ownership. Vagit Alekperov owns 20.87 per cent of the shares (Annual Report 2012 p.99),

18 Forbes Top 2000 global companies May 2013 available at: http://www.forbes.com/global2000. Accessed 2 January 2014

19 Gazprom, Sberbank, Rosneft, LUKOIL, TNK-BP (to 2013), VTB bank, NOMOS-BANK, Inter Rao, Aeroflot, Mechel, X5 Retail, Severstal, Rostelecom and Sistema. 
though other directors individually own less than 1 per cent. Major owners are ING Bank (Eurasia) (75.94\% on 1 January 2012), Depositary-clearing company 8.47 per cent, National depositary centre 5.52 per cent, SDK Garant $3.93 \%$ and OJSC URALSIB 1.42 per cent; Lukoil claims that it has more than 50,000 individual and legal entities owning its shares. The discrepancy in the total number of shares (which sum to greater than 100) is due to the fact that directors' holdings include shares directly owned and also held through beneficiaries. Pipelines and railroads used to transport the oil products are state owned companies; gas is transported by Gazprom which also sells LUKOIL gas production. In its Annual Report for 2012, very close links are shown between its Board members, the Russian government and other institutions. Of the twelve directors listed in the 2012 annual report eight are Russians and educated in Russia. The company is a Russian one with global pretensions. It is noteworthy that the Annual Report lists the state honours bestowed on the directors thus emphasising their national identification. Its Chairman, Valery Grayfer is a Lenin (and others) Prize winner; Alekperov has two government prizes in science and technology; Igor Ivanov has received Russian (state) prizes; Ravil Maganov has received three orders and three medals; Sergei Mikhailov has four state medals. Alexander Shokhin has been awarded an honour for 'Services to Russia' and a medal of the Russian Security Council for 'Services to National Security'. He is one of the directors to have had significant participation in Russian politics. He was Deputy Chairman of the government of the Russian Federation Minister of the Economy, Minister for Labor and Employment (1991-94). He was elected to three State Dumas of the Russian Federation and was Chairman of the Duma Fraction, 'Our Home is Russia'. He has also been President of the Russian Union of Industrialists and Entrepreneurs. Sergei Mikhailov is a director of five other companies mainly in the banking sector. There are also foreigners on the board. One director had served as director and CEO of international auditing KPMG; Richard Matzke is one of two Americans having previously been President of Chevron Corporation. Another American is Mark Mobius. The one Italian is also a director of TREVI SpA, and the Canadian Oil Co.. A Swiss national, Ivan Pictet, is managing director of Pictet and Cie and President of the Geneva Chamber of Trade and Industry as well as being President of Geneve Place Financiere.

Gazprom $^{20}$ is a global energy company ranked 21st in Forbes top 2000 companies' list. It produces gas and transports to European and world markets, it also produces electricity. In 2012 the government of the Russian

20 Data derived from Gazprom annual Report for 2012. www.gazprom.com Annual Report 2012. Data cited as of 31 December 2012. Accessed January 2014. 
Federation controlled 50.002 per cent of Gazprom's shares. 'The governmental representatives are the members of Gazprom's Board of Directors whose powers include the approval of the financial plan and the investment program: in this way the government exercises the control over the financial flows of Gazprom'21. It has a strategy of expansion in South America, South-East Asia, Africa and the Middle East. All members of the Board are Russian and educated in Russia; in 2012 there were no foreign members. Most of the directors have prominent positions in the Russian government giving effective control of the company.

Aeroflot is the successor of the Soviet national airline and is Russia's largest airline. It is profitable and is majority owned by the Russian government. Of Aeroflot's $^{22}$ eleven elected members of the Board in 2011, all were Russians and all but one had been educated in Russia (the exception was educated in Kiev); two had followed post graduate courses -one in law and one in business studies in the USA. They collectively held 16 directorships of other Russian companies, and only one directorship of a foreign company. Three had held government posts: in the Federal agency of state property, in the Ministry of Transport Directorate of structural reforms, one had been a deputy Minister of Economic Development, one a deputy head of the government of the Russian Federation Executive Office; and one was director of economic research at the Higher School of Economics.

Mechel is a coal, coke and steel company with many sites in Russia and plants in West Virginia, the UK, Lithuania, Ukraine and Kazakhstan. Of its Board in 201123, there were two foreign members (one American and one Englishman). The others were Russians educated in mining or economics in Russia. The two foreigners were directors of five foreign companies. Only one of the directors had a state office: Vladimir Gusev, who had been head of the Federal Tax Agency of Russia.

VTB bank is the former Vneshtorgbank (Foreign Trade bank) ${ }^{24}$ and is $263^{\text {rd }}$ in the Forbes 2000 list. It is currently 75.5 per cent owned by the Russian Federation and none of its shareholders holds more than 1 per cent of its shares. It has fifteen subsidiaries in the CIS and worldwide. Expansion to the CIS and previous Soviet space is a 'key priority' of strategy (Annual report 2012). Its fifteen Supervisory Board members have only two foreign members: David Bonderman, the President of Texas Pacific Group Investment Fund who also holds directorships

21 Gazprom annual Report 2012, p. 135.

22 Annual report for 2011 from website www.aeroflot-AR2011-final.

23 Annual report for 2012, Annual rep.pdf available at Mechel website. Accessed January 2014.

24 Data here is derived from annual report for 2012, accessed January 2014

http://www.vtb.com/upload/iblock/87a/VTB_Annual_Report_2012_20130930_1635.pdf. 
in Armstrong Worldwide Industries and Ryanair; and Mathias Warnig, managing director of Nord-Stream AG of Switzerland, and a director on the boards of Rusal, and Bank Rossiya, Rosneft and Gazprom Schweitz. He is a previous chairman of Dresdner Bank. Other Board members have strong links with other Russian banks and government institutions. Some of the board members are (or were) concurrently chinovniki holding positions in the government of the RF. Alexey Uvarov, for example is director of the Department of Industry and Infrastructure under the government of the RF, and was previously deputy head of Division of the Ministry of Property Relations of the RF. Alexey Ulyukaev is deputy chairman of the Central Bank of the RF and holds the same position in Sberbank. He is also chairman of the Russian Direct Investment Trust. He has previously been first deputy Minister of Finance of the FR. He has been a member of Moscow City Duma. Muhadin Eskindarov is principal of the Federal Institute of Higher Professional Education in the Financial University of the RF; he is on the board of TMK, the Moscow Industrial Bank, Bank Vozrozhdenie, and the Russian Agricultural Bank. As in other Russian companies, a significant proportion of the directors have higher degrees in economics and many have held positions in Russian higher educational institutions. With a leadership having overlapping membership of crucial government committees, experience in the state apparatus as well as participation in other state owned companies, the bank can be relied on to support a statist policy.

Sberbank is third in Forbes's list of Russian top companies, being behind Rosneft in 58th place. Sberbank is majority owned by the Central Bank of Russia. It has a hundred million individual customers and one million business subscribers. In 2013 it had 17 directors: 6 representatives of the Central Bank of Russia, 2 representatives from Sberbank, 1 external and 8 independent directors; they include two elected members of its management (Herman Gref Chairman and CEO, and Bella Zlatkis, Deputy Chairman ${ }^{25}$. The independent and external directors include five academics Segei Guriev, Rector of the New Economic School; Vladimir Mau (Rector of the Russian Presidential Academy of National Economics and Public Administration); a representative from Rosneft. There was only one foreign adviser: Alessandro Profumo, Chairman of the Banca Monte Dei Paschi Di Siena, Italy. The remaining members of the Board are Russians educated in Russia.

NOMOS Bank is in the $1443^{\text {rd }}$ place in the top 2000 companies. According to its Annual Report and Accounts ${ }^{26}$ for 2012, it is 49 per cent owned by the

25 Data derived from: http://report-sberbank.ru/en/ar/bank-profile/bank-profile/. Accessed January 2014

26 http://ir.nomos.ru. Accessed January 2014 
Russian ICT Group (Holding Company), the principal shareholder of which is Alexander Nesis. Deutsche Bank holds 21 per cent of its shares, followed by Otkritie Securities which owns 20 per cent. Otkritie is a Russian Financial group, the major shareholder of which is Vadim Belyaev, the President of Nomos Bank. There are two other individual shareholders, Alex Mamut ( 5 per cent) and Oleg Malis ( 5 per cent). All these men have joined the Russian bank from positions within the Russian Federation. There is no foreign representation, even though Deutsche Bank is a major shareholder. Members of the board were all educated in Russia in non-elite higher educational institutions.

Rostelecom is a Russian company, 55 per cent owned by the government through Svyazinvest. It is the largest telecom network over the Russian Federation. As listed in the Annual Report of 201227, of its fourteen directors 13 are Russian and one is Armenian. All the directors were educated in Russia, economics being the most common subject; four had received post graduate education in business schools in the USA and one had studied languages in Germany. There were a total of 99 directorships in other Russian companies (during the past five years), mostly in telecommunications companies. There were 10 directorships (two of which were in Cyprus) in foreign companies. As to other positions held, one director had joint positions as professor of economics at two Russian Universities; one had been advisor to the Ministry of telecommunications and mass communications of the Russian Federation; other had been a Deputy Governor of the Krasnoyarsk region and deputy chairman of the Krasnoyarsk government. Igor Shchegolev had been a member of the Presidential administration (2002-2008) acting as chief of Protocol of the Russian president and had also been Minister of Telecom and Mass Communications 2008-2012.

Inter Rao UES's business is in power generation and electricity supply. It also exports energy and has joint ventures with General Electric and Worley Parsons. As of February 26, 2014, its major owners are state entities such as Rosneftegaz (28 per cent) and Norilsk Nickel (12.3 per cent); minority shareholders own 16.65 per cent.

The biographies of retiring and new members of Inter Rao UES ${ }^{28}$ showed that only one director was of foreign origin (Ronald Pollett, President \& CEO of GE in Russia and CIS). Of the others all had been educated in Russia. Most had first degrees in science subjects and later studied economics or finance at postgraduate level. Except for Pollett, none held directorships in companies outside

27 Data from Annual Report for 2012. Rostelecom website. Accessed 15 January 2014

28 From annual report for 2012 AGM held on 25 June 2013. www.interrao.ru Accessed 14 Jan 2014.

Data here based on all directors in post in 2012 and those elected in 2013. 
the CIS. (There were two directors who held positions in Latvia, Latvijas Gaze and Lithuania). Most held multiple positions on the boards of other Russian companies - a total of 110 directorships between them. Two had held senior positions in the Russian government: in Russian government: Oleg Budargin (Chairman of the Management Board, JSC Federal Grid Company of Unified Energy System) had been governor of Tamyr Autonomous Okrug 2003-2007; Boris Kovalchuk, Chairman of the Management Board, JSC Inter Rao UES, had been head of the national priority projects - a department in the Russian Federation; he had also been an assistant to the First deputy Prime minister of the government of the Russian Federation. Vladimir Strzhalkovsky had been CEO of the Federal agency for tourism, head of the commission intergovernmental commission for trade and economic collaboration with Indonesia, Greece, Spain, Bulgaria, Netherlands and Cyprus. Igor Sechin, President and Chairman of the Management Board, Rosneft had been a deputy prime minister in the Russian Federation and chief of staff of the presidential exec office and an aide to president of Russian Federation 2004-8.

Rosneft is the second largest Russian company on Forbes list, ranking $34^{\text {th }}$ in the top 2000 companies. In the period 2007-2012, the Russian government owned 75.16 per cent of the shares of Rosneft through Rosneftegaz which was 100 per cent state owned. (Individuals owned less than 1 per cent stakes of the shares $)^{29}$. Rosneft purchased TNK-BP in 2013. Of its nine board members, seven are Russians and educated in Russia; the remaining two are Swiss citizens one of whom, Hans-Joerg Rudloff, has been Chairman of Barclays Investment Bank. Many have held prominent positions in other Russian companies, the Board of the Russian Union of Industrialists and Entrepreneurs as well as leading academic posts. The Chairman of the Management Board, Igor Sechin, who between 2000 and 2004 was Deputy Head of the Administration of the President of the Russian Federation and from 2004 combined this position with that of Aide to the President. From 2008 to 2012 he was Deputy Chairman in the Russian Government.

Under the post-2012 Presidency of Putin, the tide of state appointments to company boards has strengthened ${ }^{30}$. With some important exceptions, the presence of foreign directors is rare. Russian transnationals share many directors with other Russian companies. One feature which marks them out from Western companies is the greater participation of directors from other sectors, especially

29 Data here taken from Rosneft annual report for 2012 available at website. Data on ownership, p. 129.

30 On 27 January 2014, proposals were made for the return of state officials to the boards of RusHydro, Transneft, Rosneftegaz, Russian Grids, VTB Bank, Rosselkhozbank and Russian Railways (RIA Novosti 27 January 2014). 
higher education. Vladimir Mau, for example, is on two multinational boards as well as being (or having been) a Rector of two Higher educational institutions. Others participate on the Executive Board of the Russian Union of Industrialists and Entrepreneurs facilitating participation between state companies, state apparatuses and private companies. Overall, the Russian transnationals are not just 'state' companies, but 'national' ones even under private ownership. They are subject to state leadership and predisposed to conform to the interests of the state as well as being profit making entities. In return, their directors receive honours from, and social recognition by, the President.

However, there are a number of companies which are more like Western companies in composition and recruitment. Such companies have more foreigners on their boards and many of their Russian members have been educated at Western business schools. They provide the basis for a more cosmopolitan faction of the Russian economic elite.

\section{Russian Cosmopolitan Transnationals}

Sistema is a privately owned company ranked 385th in the Forbes list. It pursues neo-liberal objectives. Its vision is to build a 'first class Russian company that grows long-term shareholder value.' (p.7 of the 2016 Annual Report) ${ }^{31}$. Its geographical focus is Russia and the CIS. It is a conglomerate. Its main subsidiaries (over $50 \%$ of ownership) are in Mobile TeleSystems, Sistema Shyam TeleServices, MTS Bank, RTI (technology), Detski mir (retail), Medsi (health care), Targin (oilfield), Bashkir power grid, Segezha group (pulp and paper), Leader-Invest (real estate) and Agroholding Steppe (agriculture). (pp. 15-16). 62.4 per cent of its revenue came from MTS. (Mobile and fixed voice telephone, broadband, internet, pay TV and entertainment services).

Its shareholding is dominated by the company's founder, Vladimir Evushenkov who owns 64.2 per cent of the shares. Detailed biographies of the member of the Board of Directors are to be found in the Annual Report for 2012. There is a considerable overlap though, the British public figure, Mr Peter Mandelson, is an additional member in 2016.

The Chairman is Vladimir Evtushenkov. A Russian graduate from the Moscow Mendeleev Chemical-Engineering Institute and the Economics Faculty of Moscow State University. In the Soviet period he worked as an engineer and

31 http://www.sistema.com/fileadmin/user_upload/results_disclosure/2017/1se_annual_report.pdf. Accessed 30 April 2017 
founded Sistema in 1992. He is its principle share holder. The Deputy Chairman is Alexandr Goncharuk. A Ukrainian who graduated from the Sevastopol Higher Navy and Engineering School. He owns 1.0032 per cent of the capital. Brian Dickie is British with an English degree from Oxford as well as an MBA from Harvard Business School. He has worked in the USA, Europe and the Asia-Pacific Region. He is not a shareholder.

Sistema pursues a neo-liberal agenda within the CIS. Its Annual Report devotes ten pages to it social responsibilities and endorses the Principles for Responsible Investment developed under the United Nations. It supports charity and provides social support and promotes art and culture (particularly the Russian Museum). It also supports refugees from Ukraine. It has very few direct links with the Russian government. Sistema is an example of a Russian based company pursuing neo-liberal policies tempered by Corporate Social Responsibility. The company is not global but operates within the CIS with interests in Ukraine and Central Asia. The President can probably rely on the company for supporting a Eurasian political agenda.

X5 Retail is a retailer owning supermarkets and convenience stores. It comes near the bottom of the Forbes list, ranked at 1491 in 2014. There are 7 directors $^{32}$. Three are Russian, one American and three West Europeans. All were educated in their own countries. They collectively have 5 directorships of Russian companies and four of foreign ones. Herve Defforey, the Chairman had been managing director of Carrefour and a member of its board, he also had had senior positions at Chase Manhattan Bank, EBRO Agricolas and Nestle. Mikhail Fridman, a founder of Alfa Bank and Chairman of its Board of Directors, is also a Board member of the Council of Foreign Relations USA. There are no chinovniki on the board.

The Severstal group of companies is an integrated steel manufacturer and is listed on several stock exchanges. In recent years it has grown enormously and has two modern facilities in the USA. Its goal is to expand internationally; currently 35 per cent of its production from Russia is exported. The board reflects its international character. Of its ten board members in 2011, only five are Russian nationals: there are two Englishmen, one American, one German and one Yugoslav. Alexey Mordashov is CEO of Severstal and chairman of World Steel Association (Belgium); he is head of the Russian Union of Industrialists and Entrepreneurs, serves on the Entrepreneurs council of the Government of the Russian Federation and is a member of the EU-Russian Business cooperation council as well as the Atlantic Council President's International Advisory Board. The American member, Ronald Freeman, has (at least) six

32 Data from Annual Report for 2012. X5 Retail Group website. Accessed January 2014 
directorships of foreign companies and two Russian ones; he is a member of the executive committee of the Atlantic Council. Collectively, the members mention 21 directorships of foreign companies and eleven Russian ones, though this undoubtedly is an underestimate as many 'other companies' are not listed. Two of the Russian directors, in addition to their Russian education, attended business schools in Britain and the United States; many also had managerial positions in Western firms, such as Coca Cola and Sun Interbrew. This is clearly a company which sees the way ahead through global exposure.

\section{Hybrid Economic Elites in Russia}

In the transformation of Russia, elites originating in the nomenklatura were widely considered to be key political movers ${ }^{33}$. While the communist apparatus was disbanded, the networks remained. Initially, there was no class system based on property relations. The formation of a governing elite in Russia led to the development of a capitalist class. In Russia the class was nurtured by the elite, whereas in the United Kingdom elites have grown out of classes. Russia is a hybrid system. The administrative ruling elite plays a significant role in the control of companies. However, it coexists with a more autonomous international business elite composed of Russians and foreigners, similar to the globalized boards identified in the UK. Bottomore's second category is closest to the Russian case. But not completely - as the post-Soviet political elites created a capitalist class system.

Such differences in social and economic interests promote national and global legitimating ideologies. The more globalized corporations with foreign participation can be expected to support a neo-liberal economic and political agenda. They provide a counterpoint to the statist leadership. Their presence may also explain the neo-liberal thinking by some in the economic and political elites. The conflict is reflected in foreign affairs (which cannot be considered here).

The current Russian ruling elite has to accommodate challenges from three counter-forces of interests located both domestically and abroad. First, foreign globalizing companies which seek to take over companies in host countries (BP

33 Transition theory associated with writers such as Schmitter, O'Donnell, Di Palma, and Higley, shifted the focus to elites engaging in "compacts" and settlements, with actors "crafting" constitutions and institutions to a democratic design. O'Donnell and P. C. Schmitter 1986; Higley and Burton, (1989): 17-32; Di Palma (1990); Higley and R. Gunther, (1992). 
is an example here). Second, Russian national globalizing companies (such as Lukoil) which seek a global presence. Putin is confronted by domestic globalizing elites seeking a place in the world order as well as foreign ones seeking the same result. Third, a liberal democratic intelligentsia. Elites influence rulers and their interests reflect their different sources of power: moral, economic, political and administrative. The Russian economic elite structure is still national in form. Globalizing elites have less salience in Russia than in other European postsocialist societies. Unlike other globalizing economies, Russia has the means to establish a form of economic national sovereignty.

Such an alternative economic nationalism is a challenge to neo-liberalism. President Putin is backed by administrative control of many major companies as well as security organisations. Concurrently, he protects the interests of a Russian bourgeoisie by not threatening the legitimacy of private property. (The conflict with Berezovsky over Yukos was not about the legitimacy of property rights but the misuse of property rights). The Russian ruling elite structure is one with a growing consensus around a ruling class composed of the upper state bureaucracy (chinovniki) and nationally-based state and private business groups. Compared to the more neo-liberal economies, there is a stronger compatibility between the ruling political elite and the public. Hence Vladimir Putin's turn to national conservatism and economic nationalism are politically and economically rational and rest on the class and elite structures. As the state has significant ownership as well as bureaucratic control of the economy, the political elites can exercise considerable power over business interests.

The Russian leadership is faced with a number of dilemmas. To move into the world economy, as advocated by some business interests, would weaken the nation state which is the support base of national capitalists and concurrently strengthen neo-liberal foreign interests. President Putin has secured limitations on foreign ownership (Yukos seizure is an example) making the state a major stake holder in many but not all Russian global companies. However, the globalizing domestic economic elites - home based privately-owned globalizing companies (like Mechel) seek a larger global market which is facilitated by neoliberal policies. Currently, this group has a much weaker political and social base though oligarchs through their considerable wealth can influence or even veto the Presidential elites. They provide a source of neo-liberal opposition. Such groups have influence on the political elites and account for the continuation of neoliberal policies and attitudes. For example, the basic economic presuppositions of the Eurasian Union, like those of the European Union, are free mobility of labor, capital, goods and services. This is in contradiction to the political claims of the Eurasianists for sovereignty of the nation state. It also limits state planning of investment and labor location. 
President Putin has sought to reverse neo-liberal tendencies and to legitimate an alternative nationalist economy policy through 'sovereign democracy'. His Russian conservatism is similar in character to that of traditional Western national conservative parties. However, Russia (as well as China) has significant global or international companies whose interests would be enhanced through a neo-liberal policy which would facilitate entry to world markets and likely increased growth and higher profits. Consequently, Putin's national ideology pits the ruling political elite against counter economic elites domestically as well as foreign neo-liberal powers.

\section{CONCLUSIONS}

Globalization has led to the weakening of the powers of national political elites as nation states have lost powers to global companies and institutions. Countries have been differentially affected by these changes. In many, the locus of political power has moved away from governments and national parliaments. This is a consequence of three major developments. First, the rise of global companies which undermine national companies and political institutions. As a consequence, national economic elites lose power to transnational ones and national parliaments become marginalised. National boundaries become porous because multinational agreements replace bilateral ones. Second, in globalized economies, political legitimation is derived from neo-liberal ideology which is a comprehensive doctrine imposing competitive market processes and values on political, social as well as economic organisations. Consequently, neo-liberalism as a non-territorial form of power undermines national elites. The ideology of neo-liberalism has legitimated the primacy of global markets which work to the interest of a new class configuration. Third, nation states are eclipsed by the intrusion of global and regional markets. States are subject to competing regional and international institutions which restrict their powers of law making thus marginalising national political elites. National capitalist classes have been marginalized by the rise of global capitalist interests. The market's 'invisible hand' does not require regulation, and the rules of global markets, when necessary, have been enforced through international and regional organizations.

Transnationals have most to gain from market freedoms ensured by neoliberalism and they can act legitimately to further profits though market relations - quite independently of state governments. Transnational companies need states to secure rights to property and for the repatriation of profits. Study of the boards of companies shows that they recruit members of the political elites 
mainly for networking and knowledge. Also the earnings of foreign subsidiaries of home based companies lead to a concern about the political and economic stability of regimes in host countries - where their assets and profits are located. Repatriated profits from affiliates abroad are often more important than exports from and sales in the home country.

Scrutiny of the boards of British transnationals showed that they have become socially detached from national political elites. Globalization reduces the effectiveness of governments towards citizens; it leads to policies which for many countries placate foreign financial interests. Thus national political elites not only lose power but also legitimacy. Profits on foreign loans benefit the financial company in the home country; losses leading to bankruptcy are borne by the governments of the host country. The incumbent political elites have responded to transnational interests rather than domestic ones. Political leaders respond to the rise of globalizing companies and globalized states and institutions which favor neo-liberal solutions. National elites lose influence and national elite consensus is replaced by charismatic leaders. As noted by Pakulski and Körösényi (2011, p.3) 'leader democracy' is a political system in which leaders play 'an increasingly central role in integrating the political elite... '. They list as 'strong and popular leaders' - Margaret Thatcher, Ronald Reagan, Bob Hawke, Helmut Kohl, Lech Walesa, Nelson Mandela, Gerhard Schroeder, Tony Blair, Junichiro Loizumi, George W. Bush, Nicolas Sarkozy and Barack Obama (p.9). To which we might add Vladimir Putin, Donald Trump and Marine Le Pen who react against globalizing elites. Following this logic, political leaders then contrive to legitimate their policy in terms of their own national interests.

Globalization moves capitalism out of a nation state framework and neoliberalism legitimates markets to resolve conflicts of interest. Alternative economic policies are articulated in different political contexts, in different social and economic formations. The most important alternatives under contemporary capitalism are various forms of economic nationalism articulated by mainly right wing nationalist political movements in countries as different as the USA (Donald Trump), the UK (Theresa May's Brexit), France (Marine Le Pen), Hungary (Orbán) and a form of state capitalism in China. These propose alternative forms of capitalism. Just which form can be adopted is a matter of the distribution of power within states and also the distribution of economic and political power between states. Their common characteristic is an ideological rejection of neo-liberal policies and the articulation of policies which promote domestic interests, if necessary at the cost of regional and international allegiances. Such populist movements promise an elite circulation.

Russia is a hybrid system, with competing economic elites based on the ownership of property. Other countries have been less affected by, or have resisted 
the consequences of, globalization. Russia is one such example being much less integrated into the dominant capitalist regional, economic, political and military blocs. Its global class interests are much weaker than in Western globalizing states. Political elites in Russia have greater political space to respond to, and to advocate, national interests. Consequently, national elites (military, economic and political) are more influential in the contest with globally oriented ones. Examination of the boards of Russia's major companies indicates a hybrid pattern. There are many companies with a high interpenetration between the economic and political elites. Board members show a significant participation of government executives, such boards are composed of Russian born and educated members. President Putin not only responds to, but regulates, national capitalist interests who retain strategic powers in the economy. Russia is moving towards an administratively coordinated state-led economy. Unlike other states locked into a globalized economic system, Russia has the means to establish a form of national capitalism. In this paper I have contended that the economic political basis of national capitalism is in place. The essential component of the power of the ruling elite is administrative control of crucial energy and financial companies. This is the second of Bottomore's categories. The Russian counter-political and economic elites allied to global class interests (legitimated by neo-liberalism) challenge the political power of elites having a national base (legitimated by national sovereignty). Political leadership is a key variable in tipping the balance one way or another. Western political elites, in support of these counter elites in Russia, utilize their political, economic and media power to weaken national elites and to secure leaders with a neo-liberal globalizing world view. Their foreign policy goal is to bring all states into the neo-liberal world system.

\section{REFERENCES}

Bottomore, T.B. Elites and Society. London: Penguin 1964 (Reprinted 1982) p. 44. Crouch, C. (2010), 'The Global Firm: the Problem of the Giant firm in Democratic Capitalism'. In D. Coen - W. Grant - G.Wilson (eds) The Oxford Handbook of Business and Government. Oxford: OUP, pp. 148-172.

Dicken, P. (2003), Global Shift: Reshaping the Global Economic Map in the 21st Century. London, Sage

Di Palma, G. (1990) , To Craft Democracies: An Essay on Democratic Transitions. Berkeley, University of California Press

Harris, J. (2006) The Dialectics of Globalisation. Newcastle; Cambridge Scholars Press. 
Higley, J. - M. G. Burton (1989), The Elite Variable in Democratic Transitions and Breakdowns, ASR 54: 17-32

Higley, J. - R. Gunther, eds. (1992), Elites and Democratic Consolidation in Latin America and Southern Europe. Cambridge, UK, Cambridge University Press

Higley J.- J. Pakulski, Elite and Leadership Change in Liberal Democracies, Comparative Sociology, Vol 6 (2007) (pp. 6-26)

Mann, M. (2013), The Sources of Social Power. Vol. 4: Globalisation 1945-2011. Cambridge, CUP

O'Donnell, G. - P.C.Schmitter, (1986), Transitions from Authoritarian Rule: Tentative Conclusions about Uncertain Democracies Baltimore and London, Johns Hopkins University Press

Ohmae, K. (1995) The Nation State. New York, Free Press

Pakulski, J. - A. Körösényi (2011), Toward Leader Democracy. London, Anthem Press

Rodrik, Dani (2011), The Global Paradox: Why Global Markets, States and Democracy Can't Coexist. Oxford University Press, p. 86

Sklair, L. (2002), Globalisation. Oxford, Oxford University Press

Summers, L. (2008), 'America Needs to Make a New Case for Trade', Financial Times, 27 April

WIR (followed by date), World Investment Report (Various dates), UNCTAD, Geneva 


\section{APPENDIX I BRITISH TOP COMPANIES}

$\begin{array}{lrllrrr}\text { Company } & \text { Rank } & \text { Industry } & \begin{array}{l}\text { Market } \\ \text { Value }\end{array} & \text { Sales } & \text { Profits } & \text { Assets } \\ \text { Royal Dutch Shell } & 11 & \text { Oil \& Gas Operations } & 234.1 & 451.4 & 16.4 & 357.5 \\ \text { HSBC Holdings } & 14 & \text { Major Banks } & 192.6 & 79.6 & 16.3 & 2671.3 \\ \text { BP } & 17 & \text { Oil \& Gas Operations } & 148.8 & 379.2 & 23.6 & 305.7 \\ \text { Vodafone } & 38 & \text { Telecommunications } & 96.9 & 65.1 & 31.8 & 235.6 \\ \text { Rio Tinto } & 109 & \text { Metals \& Mining } & 103.8 & 51.2 & 3.7 & 111 \\ \text { GlaxoSmithKline } & 116 & \text { Pharmaceuticals } & 128.8 & 41.4 & 8.5 & 69.7 \\ \text { Aviva } & 143 & \text { Life, Health Insurance } & 24.1 & 53.8 & 3.1 & 449.9 \\ \text { Barclays } & 160 & \text { Major Banks } & 64.6 & 55 & 0.8 & 2173.4 \\ \text { National Grid } & 168 & \text { Natural Gas Utilities } & 49.6 & 23.4 & 3.9 & 83.9 \\ \text { AstraZeneca } & 183 & \text { Pharmaceuticals } & 82.3 & 25.7 & 2.6 & 55.9 \\ \text { Lloyds Banking } & 391 & \text { Major Banks } & 89.9 & 58.6 & -1.3 & 1402.9 \\ \text { Royal Bank of Scotland } & 424 & \text { Major Banks } & 59.8 & 38.3 & -13.4 & 1702.4\end{array}$

Data in billion US\$, Source: Forbes Top 2000 global companies available at: http://www.forbes.com/ global2000. The rankings here are taken from the 2014 list. http://www.forbes.com/companies/ . Note that data in text may be drawn from lists for other years.

\section{APPENDIX II RUSSIAN TOP COMPANIES}

\begin{tabular}{|c|c|c|c|c|c|c|}
\hline Company & Industry & Rank & $\begin{array}{l}\text { Market } \\
\text { Value }\end{array}$ & Sales & Profits & Assets \\
\hline Gazprom & Oil \& Gas & 21 & 88.8 & 164.6 & 39 & 397.2 \\
\hline Rosneft & Oil \& Gas & 34 & 70 & 142.6 & 12.8 & 229.4 \\
\hline Sberbank & Fin Serv & 58 & 51.5 & 56.5 & 11.4 & 554.2 \\
\hline LukOil & Oil \& Gas & 83 & 47.7 & 119.2 & 7.8 & 109.4 \\
\hline TNK-BP & Oil \& Gas & 159 & 33 & 43.3 & 7.6 & 43.3 \\
\hline VTB Bank & Fin Serv & 263 & 14.6 & 22.8 & 2.4 & 262 \\
\hline Sistema & Telecommunications & 384 & 9.8 & 35.5 & 2.3 & 44.4 \\
\hline Rostelecom & Telecommunications & 907 & 6.8 & 10 & 0.7 & 16.8 \\
\hline Severstal & Iron \& Steel & 1309 & 6.3 & 13.3 & 0.1 & 14.5 \\
\hline Inter Rao & Electric Utilities & 1324 & 2.4 & 20.8 & -0.7 & 15.6 \\
\hline Nomos Bank & Fin Serv & 1443 & 3.1 & 3.4 & 0.4 & 31.9 \\
\hline X5 Retail & Food Retail & 1491 & 4.5 & 16.8 & 0.3 & 8.6 \\
\hline Mechel & Iron \& Steel & 1539 & 0.5 & 11.3 & -1.7 & 14.6 \\
\hline Aeroflot RIA & Airline & 1974 & 1.9 & 4.9 & 0.5 & 5.2 \\
\hline
\end{tabular}

Data in billion US\$; http://www.forbes.com; TNK-BP and Aeroflot from the 2013 list others from 2014 list, http://www.forbes.com/companies 